\title{
PRAVNO UREĐENJE POLOŽAJA PRIVATNIH VOJNIH KOMPANIJA
}

\section{LEGAL REGULATION OF THE STATUS OF PRIVATE MILITARY COMPANIES}

\author{
Boris Krivokapić \\ Poslovni i pravni fakultet, „MB Univerzitet“, Beograd, Srbija
}

CMESTE

JEL kategorija rada: $\mathbf{K} 23$

\begin{abstract}
Apstrakt
U naše vreme sve veći značaj imaju privatna vojna i bezbednosna preduzeća, poznata kao privatne vojne kompanije (PVK). Njihova rastuća brojnost, sve veća finansijska ali i oružana snaga, činjenica da zapošljavaju sve veći broj ljudi, a naročito sama priroda njihovog biznisa koji se tiče pružanja usluga u domenu bezbednosti, obaveštajnog rada, naoružanja, logistike itd. sve do neposrednog učešća u oružanim operacijama, pa i onima van granica države u kojoj im je sedište, dovode do toga da ovi subjekti imaju sve veću ulogu ne samo u dešavanjima unutar pojedinih država, već $i$ u međunarodnim odnosima. Nakon kratkog osvrta na pojam PVK i neke od pravnih pitanja vezanih za njih, autor se bavi problemom međunarodnog regulisanja položaja PVK na univerzalnom i regionalnom nivou, s tim da se osvrće i na Dokument iz Montreja, Kodeks ponašanja za pružaoce privatnih bezbednosnih usluga i neke druge dokumente. Autor zaključuje da sve ukazuje da je potrebno što pre na univerzalnom (svetskom) nivou stvoriti nove međunarodnopravne okvire koji bi što potpunije regulisali najvažnija pitanja, kao što su definisanje najvažnijih pojmova; unifikacija uslova i načina za osnivanje, licenciranje i registraciju PVK; prava i obaveze PVK i njihovog osoblja; međunarodni nadzor nad PVK i njihovim osobljem; odgovornost svih uključenih aktera; razlika između člana osoblja PVK i plaćenika; pravila vezana za prelazak oružja i opreme PVK preko državnih granica itd. Za sada, i dalje mnogo toga je sporno - šta bi i kako trebalo regulisati univerzalnim međunarodnim ugovorom, ko bi trebalo da su njegove članice (samo države ili i neki drugi subjekti), koje mehanizme međunarodnog nadzora bi trebalo predvideti itd., pa čak i na to da li je u ovom trenutku uopšte potrebno regulisati ovu materiju na taj način.
\end{abstract}

Ključne reči: Privatne vojne kompanije, međunarodno pravo, međunarodni odnosi, bezbednost

\begin{abstract}
In our time, private military and security companies, known as private military companies (PVK), are becoming increasingly important. Their growing number, increasing financial and armed strength, the fact that they employ an increasing number of

Adresa autora:

Boris Krivokapić

䒠-7krivokapicboris@yahoo.com people, and especially the very nature of their business in terms of providing services in the field of security, intelligence, weapons, logistics,
\end{abstract}


etc., up to direct participation in armed operations, even those outside the borders of the state in which they are based, lead to the fact that these entities have an increasing role not only in events within individual states, but also in international relations. After a brief review of the concept of PVK and some of the legal issues related to them, the author deals with the problem of international regulation of the position of PVK at the universal and regional level and considers Montreux Code of Conduct for Private Security Service Providers and some other documents. The author concludes that everything indicates that it is necessary to create new international legal frameworks at the universal level as soon as possible, which would regulate the most important issues such as defining the most important terms; unification of conditions and ways for establishment, licensing, and registration of PVK; rights and obligations of PVK and their staff; international supervision of PVK and their staff; the responsibility of all actors involved; the difference between a PVK staff member and a mercenary; rules related to the crossing of PVK weapons and equipment across state borders, etc. For now, much remains controversial - what and how should be regulated by a universal international treaty, who should be its members, what mechanisms of international supervision should be provided for, etc., and even on whether it is at all necessary at this time.

Keywords: Private Military Companies, International Law, International Relations, Security

\section{UVOD}

\subsection{Pojam privatnih vojnih kompanija}

Savremenu stvarnost, podrazumevajući i međunarodne odnose $i$ ono što se događa $u$ državama, sve više karakteriše postojanje novih subjekata koji se nazivaju različitim imenima s tim da se obično koristi termin „privatne vojne i bezbednosne kompanije“ ili samo „privatne vojne kompanije“ („PVK“). ${ }^{1}$

Najprostije rečeno, radi se o privatnim preduzećima, a sve više i velikim transnacionalnim kompanijama, koji vladama ili nekom drugom ko je voljan da za to plati, nude obuku, naoružanje, obaveštajne usluge, obezbeđenje lica i objekata itd., sve do operativnog korišćenja sopstvenih, kvalifikovanih, dobro utreniranih i kompletno naoružanih i opremljenih jedinica.

Za sada najpreciznija definicija ovih subjekata data je u Dokumentu iz Montrea (2008) o kojem će kasnije biti više reči. Premda koristi naziv "privatne vojne i bezbednosne kompanije“, Dokument se suštinski odnosi na ono što ovde nazivamo privatnim vojnim kompanijama i precizira („Predgovor“, tač. 9/a) da su to:

\footnotetext{
1 Prva je bila je Watchguard International koju su 1965 , sa sedištem u Londonu osnovala dva bivša britanska potpukovnika. Pružala je usluge iz domena vojnog konsaltinga, vojne obuke, logistike itd. i uglavnom delovala na prostoru Persijskog zaliva. Prestala je sa radom 1972. Poslužila je kao uzor za osnivanje ostalih privatnih vojnih kompanija.
}

„privatna preduzeća, koja pružaju vojne i/ili bezbednosne usluge, nezavisno od toga kako sama sebe opisuju. Vojne i bezbednosne usluge podrazumevaju, posebno, oružano obezbeđenje i zaštitu lica i objekata, takvih kao što su konvoji, zgrade i druga mesta; održavanje i korišćenje borbenih sistema; ${ }^{2}$ čuvanje zatvorenika; savetovanje ili obuku lokalnih vojnih snaga ili bezbednosnog osoblja."

Istu tu definiciju doslovno koriste i Međunarodni komitet Crvenog krsta i nadležni organi UN, među kojima i Radna grupa za pitanje korišćenja plaćenika kao sredstva za kršenje ljudskih prava i ometanje ostvarivanja prava naroda na samoopredeljenje i Generalna skupština UN (International Committee of the Red Cross, 2013; General Assembly, 2018, par. 10, p. 4).

\subsection{Najvažniji problemi}

Sve veća brojnost PVK, sve veća finansijsku ali i oružanu snagu, činjenica da one zapošljavaju sve veći broj ljudi, a naročito same priroda njihovog biznisa koji se tiče pružanja usluga u domenu bezbednosti, obaveštajnog rada, naoružanja, logistike itd. sve do neposrednog učešća u oružanim operacijama, pa i onima van granica

2 „Korišćenje borbenih sistema“ je eufemizam, tj. način da se nešto (ovde: neposredno učešće u borbama) kaže u drugom, blažem obliku. Jasno je da se ne misli na korišćenje borbenih sistema (oružja) u lovu, na sportskom takmičenju i slično. 
države u kojoj im je sedište, imaju za posledicu da ov pojava privlači sve veću pažnju.

Ostavljajući po strani ostale probleme (bezbednosne, ekonomske, ekološke itd.) ovde ćemo se pozabaviti samo samo određenim pitanjima pravne prirode.

Jedan od njih je uloga odn. pravna pozicija država. $U$ vezi sa PVK razlikujemo četiri vrste država:

1. matična država - država u kojoj je sedište odnosne kompanije;

2. država ugovornica - država koja je naručilac posla koji obavlja PVK;

3. teritorijalna država - država u kojoj naručeni posao treba da bude obavljen i

4. država državljanstva - ona čije državljanstvo ima osoblje PVK.

Događa se da se neke od tih uloga spajaju u istoj državi. Tako npr. država u kojoj je sedište PVK može angažovati kompaniju da na njenoj teritoriji obavi određeni posao - npr. izvrši obuku snaga reda ili specijalnih jedinica, čuva lica i objekte itd. Ako je još i osoblje koje PVK koristi za izvršenje tih zadataka regrutovani iz redova državljana odnosne države, u pitanju je sticaj u istoj državi matične države, države ugovornice, teritorijalne države i države državljanstva. Ipak, takve situacije su u praksi retke.

Kada je reč o konkretnim problemima, jedan od najvećih je pitanje zakonitosti postojanja i rada PVK, što se ceni prema nacionalnim propisima matične i teritorijalne države, koji nisu uvek usaglašeni. Stoga se može dogoditi da je u jednoj zemlji rad PVK dozvoljen, a u drugoj zabranjen. Tome treba dodati i zakone države ugovornice, jer oni mogu zabranjivati određene aktivnosti, pa čak i propise države državljanstva, jer neke zemlje zabranjuju svojim državljanima da učestvuju u oružanim sukobima u inostranstvu i takvo njihovo angažovanje kvalifikuju kao krivično delo. ${ }^{3}$

Jedan od naročito važnih problema je pitanje odgovornosti (Weigelt \& Marke, 2007, pp. 377394; Hoppe, 2008, pp. 989-1014; Lenhardt, 2008, pp. 1015-1034; Ryngaert, 2008, pp. 1035-1053;

3 Tako je npr. izmenama Krivičnog zakonika Srbije iz 2014. (čl. 386 a i 386b) za učešće državljana Srbije u oružanim sukobima $u$ inostranstvu zaprećena kazna zatvora u trajanju od 6 meseci do 5 godina, a ukoliko je ono ostvareno u sastavu grupe, od 1 do 8 godina. $\mathrm{Za}$
Romić \& Pavlović, 2011, str. 319-332; Huskey, 2012, pp. 193-212; Kalidhass, 2014, pp. 12-19; Anderson, 2018, pp. 307-347).

Postavlja se pitanje da li su za eventualne zločine ili nanošenje nekome štete odgovorni zaposleni PVK, kompanija, matična država, država ugovornica, teritorijalna država ili čak - država državljanstva? Zapravo, zavisno od slučaja, ima osnova za odgovornost svakoga od njih:

a. osoblja PVK - po osnovu individualne krivične i druge odgovornosti.

b. PVK - zato što su krivična dela izvršili ili štetu naneli njeni zaposleni, lica koja je sama odabrala i obučila; kojima ona rukovodi; koje ona plaća, nadzire itd.;

c. matične države - zato što PVK ima njenu državnu pripadnost, što podrazumeva odgovornost u vezi sa uslovima za registrovanje kompanije, kršenjem prava od strane kompanije i njenog osoblja itd.;

d. države ugovornice - onda kada su zločini ili šteta pričinjeni dok je PVK bila angažovana na poslovima i zadacima za tu državu, a naročito onda kada je radila po preciznim nalozima, instrukcijama ili kontrolom te države. Posebna odgovornost države ugovornice postojaće onda kada je ona angažovala PVK za poslove u drugoj državi, bez saglasnosti te države. Kada ti zadaci podrazumevaju upotrebu sile, to u nekim slučajevima može predstavljati jedan vid oružane intervencije ili akt agresije, što znači teškog kršenja međunarodnog prava.

e. teritorijalne države - zato što, premda ima nadležnost na svojoj teritoriji, nije sprečila teško kršenje ljudskih prava i druge zločine $\mathrm{i}$ nezakonitosti koje su tu počinili zaposleni PVK ili nije pronašla i kaznila krivce.

f. države državljanstva - onda kada se njenim državljanima stavljaju na teret neka posebno teška dela, kao npr. genocid, a posebno kada se može utvrditi neka posebna veza između te države i njenih državljana koji su članovi osoblja PVK (npr. lica koja su aktivni pripadnici specijalnih jedinica oružanih snaga

organizovanje učešća u ratu ili oružanom sukobu u stranoj državi zaprećena je kazna zatvora u trajanju od 2 do 10 godina. 
odnosne države, a koja obavljaju poslove za PVK za vreme odsustva ili godišnjeg odmora). Pomenuta odgovornost može biti političke, moralne i neke druge, a u nekim posebnim slučajevima eventualno i pravne prirode (npr. obaveza naknade štete žrtvama zločina).

Kada je reč o krivičnoj odgovornosti, podrazumeva se da je ona individualna i da treba da odgovara samo onaj zaposleni PVK koji je naredio ili izvršio zločin. Međutim, u praksi je u nekim slučajevima pripadnicima privatnih vojnih kompanija unapred priznat imunitet. Tako je npr. jedno vreme u Iraku osoblje američkih PVK uživalo potpuni imunitet za sve svoje postupke, ${ }^{4}$ za razliku od pripadnika oružanih snaga SAD, od kojih je jedan broj odgovarao za zločine pred američkim vojnim sudovima.

Ova i mnoga druga pitanja moraju biti precizno regulisana međunarodnim pravom, ali to za sada nije slučaj.

\section{REGULISANJE PRAVNOG POLOŽAJA PRIVATNIH VOJNIH KOMPANIJA NA UNIVERZALNOM NIVOU}

Nema nikakve sumnje da se određene norme opšteg međunarodnog prava odnose i na PVK i njihovo osoblje (Krivokapić, 2020, str. 339-353). To npr. važi za mnoga pravila međunarodnog ratnog i humanitarnog prava, međunarodnog prava ljudskih prava, međunarodnog krivičnog prava itd. Ovim normama ograničavaju se pravni okviri u kojima PVK mogu da deluju.

Međutim, još uvek nema konvencije koja bi na univerzalnom planu regulisala najvažnija pitanja koja se tiču PVK kao specifičnih subjekata.

Radna grupa za za pitanje korišćenja plaćenika kao sredstva za kršenje ljudskih prava i ometanje ostvarivanja prava naroda na samoopredeljenje, koju je 2005. u okviru UN osnovao Savet za

\footnotetext{
${ }^{4}$ Američki diplomata L. Bremer (Lewis Paul Bremer III), šef Privremene koalicione vlasti, koju su SAD nametnule nakon okupacije Iraka 2003, je 27.6.2004, neposredno pre svog odlaska izdao Naredbu br. 17 (Coalition Provisional Authority Order 17) kojom je Amerikancima, povezanim sa Privremenom koalicionom vlasti, dao potpuni imunitet $u$ odnosu na pravo i nadležnost Iraka. To je sprečilo Irak da krivično goni članove osoblja američkih PVK za bilo kakva
}

ljudska prava, izradila je Nacrt moguće Konvencije o privatnim vojnim i bezbednosnim kompanijama (PVBK). Nakon što ga je usvojio Savet za ljudska prava, Nacrt je 2010. podnet Generalnoj skupštini UN (General Assembly, 2010).

U njegovom čl. 1 istaknuto je:

"1. Imajući na umu osnovne principe međunarodnog prava o zabrani pretnje silom i upotrebe sile i suverenoj jednakosti država, svrhe ove konvencije su:

a) da potvrdi i ojača odgovornost država za upotrebu sile i ponovi značaj monopola države na zakonitu upotrebe sile u sveobuhvatnom okviru obaveze države da poštuje, štiti i ispunjava ljudska prava i da obezbedi pravna sredstva za zaštitu u slučaju kršenja ljudskih prava.

b) da identifikuje one funkcije koje su suštinski državne funkcije i koje ni pod kojim uslovima ne mogu biti prepuštene drugima.

c) da reguliše aktivnosti PVBK i podugovarača.

d) da promoviše međunarodnu saradnju između država u vezi sa licenciranjem i regulisanjem aktivnosti PVBK, kako bi se efikasnije rešili svi izazovi u punoj primeni njihovih obaveza koje se tiču ljudskih prava, uključujući pravo na samoopredeljenje.

e) da uspostavi i primeni mehanizme za nadgledanje aktivnosti PVBK i kršenje međunarodnih ljudskih prava $i$ humanitarnog prava, posebno svake nezakonite ili proizvoljne upotrebe sile počinjene od strane PVBK, u cilju krivičnog gonjenja počinilaca i pružanja efikasnih pravnih sredstava zaštite žrtvama.

krivična dela, pa i ratne zločine. Takvo stanje je trajalo do 2008. kada su na osnovu čl. 12/1/1 Sporazuma o statusu snaga (Status of Forces Agrement) zaključenog između SAD i Iraka, članovi osoblja PVK u Iraku izgubili imunitet i potpali pod krivičnu jurisdikciju Iraka (Geneva Centre for the Democratic Control of Armed Forces, 2009). 
2. U sprovođenju Konvencije, države potpisnice preduzeće se neophodne zakonodavne, sudske i administrativne mere u skladu sa postojećim ili novim odredbama svojih domaćih zakona kako bi se osiguralo da se PVBK ne bave nezakonitim aktivnostima ili da ne upotrebljavaju proizvoljno silu."

Rešenja, sadržana u Nacrtu, trebalo bi da omoguće da se unese red u ove odnose, da se obezbedi zakonitost u radu PVK i, naročito, da se spreči da te kompanije i njihovo osoblje krše međunarodno humanitarno pravo i međunarodno pravo ljudskih prava.

Značaj ovog dokumenta je i u tome što on u čl. 2 daje definicije čitavog niza pojmova kao što su privatna vojna i bezbednosna kompanija, vojne usluge, bezbednosne usluge, licenca, režim licenciranja, registar licenci, ljudska prava, izvoz vojnih $\mathrm{i} /$ ili bezbednosnih usluga, uvoz vojnih $\mathrm{i} / \mathrm{ili}$ bezbednosnih usluga, osnovne funkcije države, oružani sukob, nezakonite aktivnosti, država ugovornica, teritorijalna država, matična država itd. (Haile, 2009, pp. 1-5; Juma, 2011, pp. 1-33; Moesgaard, 2011; Del Prado, 2011, pp. 1-79; Del Prado, 2012, pp. 262-286).

Među posebno zanimljivim predloženim rešenjima je ono o uspostavljanju međunarodnog registra PVK kojemu bi države ugovornice Konvencije bile bi u obavezi da dostavljaju godišnje podatke o uvozu i izvozu vojnih i bezbednosnih usluga PVK i standardizovane informacije o PVK koje su kod njih registrovane i licencirane, čime bi se obezbedio veći nadzor parlamenta i javnosti u odnosnim državama. Predviđeno je i formiranje Međunarodnog komiteta koji bi nadzirao mere koje su države ugovornice preduzele u ostvarivanju preuzetih obaveza iz Konvencije. Konvencija bi važila ne samo za države, već i za međunarodne organizacije, u okvirima njihove nadležnosti u odnosima sa PVK, njihovom delatnošću i osobljem (čl. 1/1 Nacrta) a važila bi u svim odnosnim slučajevima, nezavisno od toga da

\footnotetext{
5 Npr. ugovori, usvojeni u okviru Saveta Evrope koji jamče pravo na život, slobodu i bezbednost; predviđaju kažnjavanju samo na osnovu zakona; zabranjuju mučenje, nečovečno ili ponižavajuće postupanje i kažnjavanje; zabranjuju diskriminaciju; regulišu držanje i nošenje oružja; itd. Tu spadaju: Evropska konvencija o ljudskim pravima (1950), Evropska konvencija o kontroli
}

li se konkretna situacija definiše kao oružani sukob ili ne (čl. 1/3 Nacrta). U slučajevima koji nisu predviđeni Konvencijom ili drugim međunarodnim sporazumima, države ugovornice ostale bi vezane principima međunarodnog prava koji proističu iz ustanovljenih običaja, principima humanosti i zahtevima javne svest (čl. 1/4 Nacrta).

Ipak, Nacrt je ostao u sadržinski nedorečen odnosi se samo na korišćenje PVK od strane država i međunarodnih organizacija, ali ne i drugih subjekata, kao npr. transnacionalne kompanije; nije predvideo nikakvu posebnu nadležnost samih UN u pogledu PVK; itd.

Gledano iz drugog ugla, on je pre spisak određenih principa, nego do kraja precizan dokument (uostalom, zato se i zove nacrtom moguće konvencije) što znači da bi pre nego što postane stvarna, pravno obavezujuća konvencija morao biti dorađen. Međutim, za sada ništa konkretno nije urađeno i teško je predvideti kada će biti potpisana relevantna konvencija, a tim pre kada će stupiti na snagu. Razlog tome je nepostojanje stvarne volje država. Većina članica UN ne podržava ideju prenošenja zakonite upotrebe sile na PVK, dok sa druge strane, najrazvijenije zemlje smatraju da bi pravno obavezujući međunarodni instrument sa regulatornim $i$ nadzornim mehanizmima bio $u$ ovom trenutku preuranjen. Izgleda da im više odgovara postojeće stanje u kojem imaju mnogo veći manevarski prostor.

\section{REGIONALNI NIVO}

Određeni odnosi koji su u vezi sa radom PVK regulisani su regionalnim ugovorima o ljudskim pravima i nekim drugim instrumentima opšteg značaja. ${ }^{5}$ Oni se, međutim, ne bave posebno PVK.

Najvažniji document Saveta Evrope koji se neposredno odnosi na ovu materiju je Preporuka Parlamentarne Skupštine Saveta Evrope br. 1858 (2009) "Privatne vojne I bezbednosne kompanije I erozija državnog monopola nad upotrebom sile"

sticanja i držanja vatrenog oružja od strane pojedinaca (1978), Konvencija o zaštiti lica u odnosu na automatsku obradu ličnih podataka (1981), Evropska konvencija za sprečavanje mučenja i nehumanih ili ponižavajućih postupaka ili kazni (1987) itd. 
(Parliamentary Assembly, 2009: Gastón, 2008, pp. 221-248; Nikač \& Korajlić, Ahić, Bećirović, 2013, str. 35-37).

Ona konstatuje trend uključivanja PVK u preduzimanje raznih zadataka $u$ vojnim $i$ bezbednosnim oblastima, koje su tradicionalno bile domen država; podvlači da su osoblje PVK i njihovi poslodavci vezani zakonima zemlje $u$ kojoj posluju, međunarodnim humanitarnim pravom i pravom ljudskih prava; primećuje da pošto aktivnosti PVK imaju prekogranične aspekte $i$ posledice, potrebno je da budu regulisane na međunarodnom nivou; ističe da Savet Evrope treba da preuzme vođstvo u procesu stvaranja odgovarajućeg međunarodnog pravnog okvira; preporučuje da Komitet ministara izradi instrument kojim bi bili regulisani odnosi država članica sa PVK i utvrđeni minimalni standardi za aktivnosti tih kompanija; preporučuje Komitetu ministara i državama članicama Saveta Evrope da podrže i kao prelazno rešenje prihvate Dokument iz Montreja; itd. Reč je, međutim, o političkom, a ne pravnom aktu, o preporuci koja ne sadrži konkretna rešenja i nema pravno obavezujuću snagu.

Zanimljiv je i Izveštaj Evropske komisije za demokratizaciju putem prava (Venecijanska komisija) "O privatnim i vojnim i bezbednosnim firmama i eroziji državnog monopola nad upotrebom sile" (European Commission for Democracy through Law - Venice Commission, 2009). Međutim, i on se uglavnom bavi političkim pitanjima i koracima koje bi trebalo preduzeti i, što je još važnije, nema pravno obavezujuću snagu.

Pravog, pravno obavezujuće propisa o PVK nema ni u okviru drugih međunarodnih organizacija. Određeni dokumenti u smislu utvrđivanja zajedničkih standarda (licenciranje, obuka, pravila ponašanja itd.) usvojeni su u Evropskoj uniji, ali i tu su još uvek sve uglavnom merodavni propisi država članica (Krahmann, 2005, pp. 103-125; Bailes, 2008, pp. 196-201; Born \& Caparini, Cole,

\footnotetext{
6 Njegov puni naziv je: Dokument iz Montreja o odgovarajućim međunarodnim pravnim obavezama $i$ dobroj praksi za države povezane sa delovanjem privatnih vojnih $i$ bezbednosnih kompanija tokom oružanih sukoba. Za tekst vidi: The Montreux Document on pertinent international legal obligations and good practices for States related to operations of private
}

2007; White \& LacLeod, 2008, pp. 965-988; Nikač \& Korajlić, Ahić, Bećirović, 2013, str. 37).

Rezolucija Evropskog parlamenta od 4.7.2017 (European Parliament, 2017) priznala je značaj PVK kao i to da njihove usluge koristi i sama EU u inostranstvu za čuvanje svojih delegacija i osoblja i podršku svojim civilnim i vojnim misijama (par. 7 , p. 84) i pozvala Komisiju da pripremi efikasan evropski regulatorni model u ovoj oblasti (par. 17, p. 85). Rezolucija, dakle, ne uređuje ovu materiju, već predstavlja samo tzv. zakonodavnu inicijativu.

\section{OSTALI DOKUMENTI}

Praksa je zahtevala da se u ovoj oblasti društvenih odnosa što pre definišu neka pravila. To je dovelo do nastanka određenih dokumenata koji nisu pravno obavezujući, ali za koje oni koji su ih usvojili veruju da mogu ispuniti postojeću prazninu.

\subsection{Dokument iz Montreja}

Prvi međunarodni akt koji je istakao međunarodnopravne obaveze država u vezi sa aktivnostima PVK bio je potpisan 17.9.2008. u Montreju (Švajcarska) te je poznat kao Dokument Montreja (2008). ${ }^{6}$

Usvojen je na inicijativu Švajcarske i Međunarodnog komiteta Crvenog krsta, u saradnji sa ekspertima iz niza država i predstavnicima tzv. civilnog društva i kompanija (ICRC).

Ima dva dela. Prvi se bavi međunarodnopravnim obavezama država koje angažuju PVK kompanije (države ugovornice), država domaćina na čijoj teritoriji PVK deluju (teritorijalne države) država u kojima su registrovane PVK (matične države) kao i obavezama samih PVK i njihovog osoblja $u$ vršenju poslova, uz insistiranje na dužnosti poštovanja normi međunarodnog humanitarnog prava i međunarodnog prava ljudskih prava. $\mathrm{Na}$ sličan način precizirane su obaveze prema unutrašnjem (nacionalnom) pravu država (prema

military and security companies during armed conflict, Federal Department of Foreign Affairs (Switzerland) \& International Committee of the Red Cross, www.icrc.org/en/doc/assets/files/other/icrc_002_0996. pdf. 
njihovom krivičnom, poreskom, radnom pravu i dr.). Drugi deo Dokumenta odnosi se na dobre prakse država u ovoj oblasti i tu su obrađena pitanja koja se tiču delatnosti PVK, postupka za izbor i unajmljivanje PVK, uslova za izbor, kontrolu i nadzor itd., sve sa ciljem da se državama pomogne da preduzmu odgovarajuće mere u skladu sa svojim obavezama prema međunarodnom pravu (Cockayne, 2008, pp. 401426; Метелина, 2012, стр. 136-138; DeWinterSchmitt, pp. 2013; Nikač \& Korajlić, Ahić, Bećirović, 2013, str. 33-34; Ralby, 2016, pp. 235263).

Već iz punog naziva Dokumenta vidi se da se on ne bavi opštim pitanjima funkcionisanja PVK nego uređuje odnose koji se tiču njihovog delovanja tokom oružanog sukoba. Dokument otvara određene probleme, predlaže konkretna rešenja (nudi najvažnije termine i definicije, na prilično kvalitetan način formuliše moguće načine rešenja određenih pitanja itd.) potvrđuje važnost međunarodnog humanitarnog prava i međunarodnog prava ljudskih prava i upućuje na najvažnije izvore tih grana međunarodnog prava, uključujući i običajno pravo. Premda predstavlja dobru osnovu za ponašanje i delovanje PVK i njihovog osoblja tokom oružanog sukoba, Dokument je dobio relativno malu podršku - do 2020. (posle 18 godina) potpisali su ga samo 56 država i 3 međunarodne organizacije - EU, NATO i OEBS. (Montreux Document Forum, 2020. Još veći problem je činjenica da Dokument nije pravno obavezujući - predstavlja jedan vid tzv. mekog prava, što znači da ima određeni značaj, ali da ne

7 Da posluju u skladu sa principima sadržanim u Kodeksu; da primenjuju odgovarajuće politike i nadzor sa namerom da postupanje njihovog osoblja uvek bude u skladu sa tim principima; da svoje ugovore sa svojim osobljem, podizvođačima i drugim stranama usklade sa Kodeksom; da se pridržavaju Kodeksa, čak i ako on nije u uključen u ugovor sa klijentom; da ne zaključuju svesno ugovore koji su neposredno i suštinski u suprotnosti sa principima Kodeksa, merodavnim nacionalnim ili međunarodnim pravom ili merodavnim lokalnim, regionalnim ili međunarodnim pravom ljudskih prava; da svoje ugovore tumače i izvršavaju na način koji je u skladu sa Kodeksom; da se pridržavaju i od svog osoblja zahtevaju da se pridržava merodavnog prava, uključujući međunarodno humanitarno pravo i pravo ljudskih prava; da neće zaključivati ugovore njima, podržavati ili servisirati bilo koju vladu, lice ili entitet na način koji bi bio suprotan sankcijama Saveta bezbednosti UN; itd. i karakter pravog međunarodnog ugovora kao izvora stvarnog, čvrstog prava (Krivokapich, 2017, str. 55-62).

Tome treba dodati da uvek ostaje otvoreno pitanje koliko se dogovorena rešenja zaista poštuju u praksi, tim pre što je reč o pravno neobavezujućem aktu, koji ne predviđa efikasne kontrolne mehanizme i sankcije.

\subsection{Kodeks ponašanja za privatne pružaoce bezbednosnih usluga}

Pripremljen je na inicijativu Švajcarske i otvoren za potpisivanje 10.11.2010. (Geneva Academy of International Humanitarian Law and Human Rights, 2013). Sa osloncem na pravila međunarodnog humanitarnog prava i međunarodnog prava ljudskih prava, formuliše opšte principe, neophodne za uspostavljanje međunarodnih standarda u oblasti privatne bezbednosti, odgovornosti privatnih bezbednosnih kompanija (skr. PBK) i poboljšanja kontrole i nadzora nad njihovim radom. (Rosemann N. 2008; Nikač \& Korajlić, Ahić, Bećirović, 2013, str. 34-35; Shah, 2014, pp. 25592573; MacLeod, 2015, pp. 128-132; Narváez González \& Valencia, 2019, pp. 79-107).

$U$ cilju obezbeđenja odgovornog i zakonitog postupanja PBK i njihovog osoblja, daje definicije 13 upotrebljenih termina, utvrđuje osnovne obaveze kompanija potpisnica, ${ }^{7}$ precizira principe ponašanja osoblja $\mathrm{PBK}^{8}$ itd.

Kada je 2010. g. otvoren za potpisivanje, potpisalo ga je 58 PBK iz 15 država, a već do septembra

8 Ti principi tiču se obaveze PBK da usvoje pravila za upotrebu sile, u skladu sa Kodeksom; upotrebe sile (preduzimanja svih razumnih mera da bi se izbegla upotreba sile, korišćenje sile u skladu sa merodavnim pravom, proporcionalnost sile pretnji i usklađenost sa situacijom, korišćenje vatrenog oružja protiv ljudi samo radi samoodbrane ili nužne odbrane drugih; itd.); pritvora i lišavanja slobode (samo po ugovoru sa državom, samo uz učešće obučenog osoblja, itd.); zabrane mučenja, okrutnih, nehumanih ili ponižavajućih postupaka ili kazni; zabrane seksualnog iskorišćavanja i zlostavljanja i rodno zasnovanog nasilja; zabrane trgovine ljudima; zabrane ropstva i prinudnog rada; zabrane diskriminacije; obaveze identifikacije osoblja PBK; obaveze registracije i licenciranja vozila i opasnih materijala kod nadležnih državnih organa; itd. 
2013. broj potpisnica se popeo na 708 kompanija iz više od 70 država. S obzirom na taj uspeh koji je ostvaren za vrlo kratko vreme, 2013. g. je sa sedištem u Ženevi, stvorena posebna asociacija (International Code of Conduct for Private Security Service Providers Association - ICoCA) čija je svrha da promoviše, upravlja i nadzire srpovođenje Kodeksa i promoviše odgovorno pružanje usluga bezbednosti i poštovanje ljudskih prava $\mathrm{i}$ nacionalnog $\mathrm{i}$ međunarodnog prava $\mathrm{u}$ skladu sa Kodeksom. Njom rukovodi Upravni odbor, ovlašćen za nadgledanje i potvrđivanje usaglašenosti postupanja udruženih kompanija sa Kodeksom. ${ }^{9}$ Od osnivanja Asociacije ne priznaje se više status potpisnice Kodeksa kao takve, već kompanije ulaze u članstvo Asociacije. Septembra 2020, u članstvu Asociacije bilo je 7 država (Australija, Kanada, Norveška, SAD, Švajcarska Švedska i Velika Britanija), 100 PVK, 39 organizacija civilnog društva (nevladinih organizacija), 41 posmatrač i 5 pridruženih članova. (Promoting Responsible Private Security..., 2020).

$\mathrm{Na}$ prvi pogled Kodeks nema veze sa međunarodnim pravom oružanih sukoba, zato što se bavi privatnim bezbednosnim, a ne vojnim kompanijama. Takav zaključak ne bi bio sasvim tačan, već zbog toga što razlika između vojnih $i$ bezbednosnih usluga nije uvek dovoljno jasna. Pored toga, pošto se bave i bezbednosnim pitanjima, u članstvu Asociacije su i mnoge PVK. Uostalom, sam Kodeks pominje obavezu poštovanja ne samo međunarodnog prava ljudskih prava, već i međunarodnog humanitarnog prava (tj. dela međunarodnog prava oružanih sukoba) što znači da su autori Kodeksa bili svesni toga da osoblje ovih kompanija često učestvuje u oružanim sukobima.

Premda je uključeno i 7 država, Kodeks nije međunarodni ugovor, već samo izraz saglasnosti postignute između samih kompanija, dakle u okvirima poslovnog sveta. Pored toga, on nije obavezujući - kompanije same odlučuju da li će ući u Asociaciju i da li će je napustiti. Štaviše, sam Kodeks (čl. 14) izričito kaže da on ne stvara nikakve pravne obaveze niti pravne odgovornosti

\footnotetext{
9 Upravni odbor ima 12 članova, od kojih 4 biraju udružene privatne kompanije, 4 organizacije civilnog društva, a 4 države.
}

za kompanije potpisnice, osim onih koje već postoje prema nacionalnom ili međunarodnom pravu. Ograničeni značaj ovog dokumenta ogleda se i u tome što premda Asociacija ima kontrolni mehanizam (kontrolu vrši Upravni odbor, a predviđen je i postupak za podnošenje pritužbi zbog kršenja Kodeksa) on nije zaista efikasan zato što pritužbe podnose kompanije jedne protiv drugih, a ne žrtve kršenja ljudskih prava, nisu propisane nikakve kazne, a ne postoji ni poseban sud pred kojim bi kompanije odgovarale ako bi kontinuirano kršile Kodeks. Stoga se sa raznih strana mogu čuti primedbe da Kodeks ne daje stvarna rešenja ni u jednoj bitnoj sferi (upravljanje, kontrola, obeštećenje, sankcije i odgovornost države) te da se zapravo radi samo o smokvinom listu koji omogućava PBK da stvore privid kako imaju i poštuju neka pravila i standarde odnosno kako je njihovo poslovanje zakonito. (Raphael, 2016, pp. 11-12).

\subsection{Ostali pravno neobavezujući dokumenti}

U ovoj materiji postoje i drugi neobavezujući dokumenti, ali je njihov značaj mnogo manji. Takvi su npr. Vodič za zakonsko regulisanje privatnih vojnih i bezbednosnih kompanija od strane država i Vodič za ugovore vojnih i bezbednosnig kompanija: Promovisanje odgovornosti i poštovanja ljudskih prava i međunarodnog humanitarnog prava. (Federal Department of Foreign Affairs..., 2016; Federal Department of Foreign Affairs..., 2017). Oba su zajedno izradili i publikovali ministarstvo spoljnih poslova Švajcarske i Ženevski centar za demokratsku kontrolu oružanih snaga. Ovi dokumenti, čiji iza kojih stoje jedna država i jedna nevladina organizacija, u najboljem slučaju mogu se nadati da će pokrenuti diskusiju i poslužiti kao neki od modela mogućih rešenja, ali ne mogu da pretenduju na to da imaju pravnu obaveznost.

\section{POTREBA REGULISANJA}

PRAVNOG

Sve ukazuje da je potrebno što pre na univerzalnom (svetskom) nivou stvoriti nove međunarodnopravne okvire koji bi što potpunije 
regulisali najvažija pitanja. Takva kao što su: definisanje najvažnijih pojmova; što veća unifikacija uslova i načina za osnivanje, licenciranje i registraciju PVK; najvažnija prava i obaveze tih PVK i njihovog osoblja; međunarodni nadzor nad PVK i njihovim osobljem; odgovornost svih uključenih aktera; razlika između člana osoblja PVK i plaćenika; pravila vezana za prelazak oružja i opreme PVK preko državnih granica i kontrolu tog oružja i opreme u cilju sprečavanja njihovog šverca, nelegalne prodaje i drugih nezakonitosti; itd. (Cockayne \& Speers Mears, 2006; Kinsey, 2008; Scheimer, 2009, pp. 609-646; Arnpriester, 2017, pp. 1189-1239; Небольсина \& Никитин, 2016, стр. 145-160).

$\mathrm{U}$ pitanju je ogroman svetski biznis koji dotiče živote mnogih, pa i interese čitave međunarodne zajednice, posebno zbog toga što je povezan sa upotrebom sile $i$ to često van granica samo jedne države.
Međutim, još uvek su mnoga pitanja sporna i to ne samo među stručnjacima za međunarodno pravo, već i među državama, međunarodnim organizacijama, pripadnicima raznih oružanih snaga, nevladinim sektorom itd., kao i, razume se, samim PVK. Sporovi se odnose već na načelna pitanja, kao što su šta bi i kako trebalo regulisati univerzalnim međunarodnim ugovorom, ko bi trebalo da su njegove članice (samo države ili i neki drugi subjekti, i koji), koje mehanizme međunarodnog nadzora bi trebalo predvideti itd., pa čak i na to da li je u ovom trenutku uopšte potrebno ragulisati ovu materiju na taj način.

Tome treba dodati da čak i kada jednog dana ova materija bude kodifikovana odgovarajućim sporazumom, veliko je pitanje koliko će kvalitetna biti njegova sadržina i, s druge strane, koliko država će uspeti da okupi među svojim članicama, da li će među tim članicama biti i najveće vojne sile sveta, da li će dosledno poštovati, itd.

\section{CITIRANA DELA}

Anderson, M. (2018). If It Looks Like a Duck: Reining in Private-Military Contractor Conduct Through the Amended UCMJ. Case Western Reserve Journal of International Law, (1), 307-347

Arnpriester, N. (2017). Combating Impunity: The Private Military Industry, Human Rights, and the 'Legal Gap'. University of Pennsylvania Journal of International Law, (4), 1189-1239

Bailes, A. J. K. (2008). Private Military and Security Companies, the European Union, and Regulation as a Tool for Efficiency. Security and Peace, (4), 196-201

Born, H., \& Caparini, M., Cole, E. (2007). Regulating Private Security Companies in Europe: Status and Prospects. Policy Paper 20, Geneva Centre for the Democratic Control of Armed Forces (DCAF), http://psm.du.edu/media/documents/reports_and_stats/think_tanks/dcaf_born_caparini_and_c ole_regulating_private_security_in_europe.pdf

Cockayne, J., \& Speers Mears, E. (2006). Private Military and Security Companies: A Framework for Regulation. International Peace Institute, www.ipinst.org/wpcontent/uploads/publications/pmsc_epub.pdf

Cockayne, J. (2008). Regulating Private Military and Security Companies: The Content, Negotiation, Weaknesses, and Promise of the Montreux Document. Journal of Conflict \& Security Law, (3), $401-426$

Del Prado, J. L. G. (2011). A United Nations Instrument to Regulate and Monitor Private Security Contractors. Notre Dame Journal of International \& Comparative Law, (1), 1-79

Del Prado, J. L. G. (2012) “A U.N. Convention to Regulate PMSCs?”, Criminal Justice Ethics, No. 3, pp. 262-286

DeWinter-Schmitt, R. ed. (2013) Montreux Five Years On: An analysis of state efforts to implement Montreux Document legal obligations and good practices, Washington College of Law, www.wcl.american.edu/index.cfm?LinkServID=B1E626D9-095E-4A28-94A94551CEA3488E 
European Commission for Democracy through Law - Venice Commission (2009) Report on Private Military and Security Firms and Erosion of the State Monopoly on the Use of Force, Study no. 531 (2009), 29.6.2009, www.venice.coe.int/webforms/documents/default.aspx?pdffile=CDL$A D(2009) 038-e$

European Parliament (2017) European Parliament Resolution of 4 July 2017 on Private Security Companies (2016/2238(ini)), 4 July 2017, https://eur-lex.europa.eu/legalcontent/en/txt/pdf/?uri=celex:52017ip0289\&rid=6

Federal Department of Foreign Affairs (FDFA) \& Geneva Centre for the Democratic Control of Armed Forces (DCAF) (2016) Legislative Guidance Tool for States to Regulate Private Military and Security Companies), Geneva, https://marsad-egypt.info/wp-content/uploads/2020/03/2018-1119_legislative-guidance-tool.pdf

Federal Department of Foreign Affairs (FDFA) \& Geneva Centre for the Democratic Control of Armed Forces (DCAF) (2017) A Contract Guidance Tool for Private Military and Security Services: Promoting Accountability and Respect for Human Rights and International Humanitarian Law), Geneva, www.mdforum.ch/pdf/contract-guidance-tool.pdf

Gastón, E. L. (2008) "Mercenarism 2.0? The Rise of the Modern Private Security Industry and Its Implications for International Humanitarian Law Enforcement", Harvard International Law Journal, No. 1, pp. 221-248

General Assembly (2010) Draft of a Possible Convention on Private Military and Security Companies (PMSCs) for Consideration and Action by the Human Rights Council, Annex to: Report of the Working Group on the use of mercenaries as a means of violating human rights and impeding the exercise of the right of peoples to self-determination, A/HRC/15/25, 5 July 2010, https://undocs.org/en/A/HRC/15/25

General Assembly (2018) Use of Mercenaries as a Means of Violating Human Rights and Impeding the Exercise of the Right of Peoples to Self-Determination, a/73/303, 6 August 2018, www.un.org/en/ga/search/view_doc.asp?symbol=a/73/303

Geneva Academy of International Humanitarian Law and Human Rights (2013) The International Code of Conduct for Private Security Service Providers, Geneva, www.genevaacademy.ch/joomlatools-files/docman-

files/Publications/Academy\%20Briefings/Icoc_web_final.pdf

Geneva Centre for the Democratic Control of Armed Forces (2009) Status of Forces Agreement between the Republic of Iraq and the United States of America, 2009, www.dcaf.ch/sites/default/files/publications/documents/us-iraqi_sofa-en.pdf

Haile, C. J. (2009) "New U. N. Draft International Convention on the Regulation, Oversight, and Monitoring of Private Military and Security Companies", International Government Contractor, (9), www.crowell.com/documents/New-UN-Draft-International-Convention-On-The-RegulationOversight-And-Monitoring-Of-Private-Military-And-Security-Companies.pdf

Hoppe, C. (2008). Passing the Buck: State Responsibility for Private Military Companies. European Journal of International Law, (5), 989-1014

Huskey, K. A. (2012) Accountability for Private Military and Security Contractors in the International Legal Regime", Criminal Justice Ethics, No. 3, pp. 193-212

ICRC. The Montreux Document, www.eda.admin.ch/eda/en/fdfa/foreign-policy/internationallaw/international-humanitarian-law/private-military-security-companies/montreux-document.html

International Committee of the Red Cross. (2013). International Humanitarian Law and Private/Security Companies - FAQ, 10 December 2013, www.icrc.org/en/document/ihl-and-private-militarysecurity-companies-faq 
Juma, L. (2011). Privatisation, human rights and security: Reflections on the Draft International Convention on Regulation, Oversight and Monitoring of Private Military and Security Companies. Law, Democracy \& Development, (1), 1-33, doi: 10.4314/ldd.v15i1.3

Kalidhass, P. R. (2014). Determining the Status of Private Military Companies under International Law: A Quest to Solve Accountability Issues in Armed Conflicts. Amsterdam Law Forum, (2), 4-19

Kinsey, C. (2008). International Law and the Control of Mercenaries and Private Military Companies. Cultures \& Conflits, 26 June 2008, https://journals.openedition.org/conflits/11502

Krahmann, E. (2005). Regulating Private Military Companies: What Role for the EU?. Contemporary Security Policy, (1), 103-125

Krivokapich, B. (2017). Myagkoye pravo v mezhdunarodnom prave, in: Lutovac M. (ed.): International Conference: "Composite Materials, Ecology, Information Technology, Economics and Law", ELaSa-2017, Proceedings, 1-3 July 2017, Tivat, Montenegro, publ. Russian Academy of Sciences et. al., pp. 55-62

Krivokapić, B. (2020). Pravni položaj osoblja privatnih vojnih kompanija prema međunarodnom pravu oružanih sukoba. u: Perović Vujačić J. S. (gl. ur.) Unifikacija prava i pravna sigurnost, Zbornik radova 33. Kopaoničke škole prirodnog prava - Slobodan Perović, Međunarodna naučna konferencija, Beograd 23.12.2020, tom III, 2020, Kopaonička škola ptitodnog prava - Slobodan Perović, Beograd, str. 339-353

Lenhardt, C. (2008). Individual Liability of Private Military Personnel under International Criminal Law, European Journal of International Law, (5), 1015-1034

MacLeod, S. (2015). Private Security Companies and Shared Responsibility: The Turn to Multistakeholder Standard-Setting and Monitoring through Self-Regulation-'Plus'. Netherlands International Law Review, 62, (1), 119-145

Metelina, O. V. (2012). Vopros statusa chastnykh voyennykh i okhrannykh kompaniy. Dokument Montre, Vestnik Chuvashkogo universiteta, (1), 36-138

Moesgaard, C. (2011). Weak International Response to the Use of Private Military Security Companies, DIIS Policy Brief, 2011, http://pure.diis.dk/ws/files/69652/PB2011_weak_international_response_web.pdf

Montreux Document Forum (2020). Participating States and International Organisations, Geneva 2020, www.mdforum.ch/participants

Narvaez Gonzalez, C. \& Valencia, K. (2019). Improving Human Rights in the Private Security Industry: Envisioning the Role of ICoCA in Latin America. Business and Human Rights Journal, (1), 79-107

Nebol'sina, M. A., \& Nikitin, A. A. (2016). Perspektivy mezhdunarodnogo regulirovaniya deyatel'nosti chastnykh voyennykh kompaniy. Vestnik Universiteta MGIMO, (2), 145-160

Nikač, Ž., Korajlić, N., Ahić, J., \& Bećirović, A. (2013) Pravna regulativa privatne bezbednosti na prostorima nekadašnje SFRJ, sa osvrtom na poslednje promene u Srbiji. Kriminalističke teme, (3-4), 27-52

Parliamentary Assembly (2009) Private military and security firms and erosion of the state monopoly on the use of force. Recommendation 1858 (2009), https://assembly.coe.int/nw/xml/XRef/XrefXML2HTML-en.asp?fileid=17711\&lang=en

Promoting Responsible Private Security: Members and Observers of the ICOCA; The Role of the ICOCA, 4. Sept. 2020, https://www.icoca.ch/

Ryngaert, C. (2008). Litigating Abuses Committed by Private Military Companies. European Journal of International Law, (5), 1035-1053 
Romić, M., \& Pavlović, G. (2011). Neki aspekti odgovornosti država za akcije privatnih vojnih kompanija. Politeia, (2), 319-332

Ralby, I. (2016). The Montreux Document the Legal Significance of a Non-legal Instrument, in Schaub, G. Jr., \& Kelty, R. eds., Private Military and Security Contractors: Controlling the Corporate Warrior, Rowman \& Littlefield, pp. 235-263

Raphael, S. (2016). Mercenaries Unleashed: The brave new world of private military and security companies, War on Want, www.waronwant.org/sites/default/files/Mercenaries\%20Unleashed,\%202016.pdf

Rosemann, N. (2008). Code of Conduct: Tool for Self-Regulation for Private Military and Security Companies. Geneva Centre for Democratic Control of Armed Forces (DCAF). Occasional Paper No. 15, https://www.dcaf.ch/sites/default/files/publications/documents/OP15_Rosemann.pdf

Scheimer, M. (2009). Separating Private Military Companies from Illegal Mercenaries in International Law: Proposing an International Convention for Legitimate Military and Security Support that Reflects Customary International Law. American University International Law Review, (3), 609646

Shah, R. (2014). Beating Blackwater: Using Domestic Legislation to Enforce the International Code of Conduct for Private Military Companies. Yale Law Journal, 123(7), 2559-2573

Weigelt, K. \& Marker, F. (2007). Who is Responsible? The Use of PMCs in Armed Conflict and International Law, in: Jaeger, T., \& Kuemmel, G. (eds), Private Military and Security Companies, VS Verlag fuer Sozialwissenschaften, pp. 377-394

White, N. D. \& MacLeod, So. (2008). EU Operation and Private Military Contractors: Issues of Corporate and Institutional Responsibility. European Journal of International Law, (5), 965-988

Received for publication: $\quad$ 18.01.2021.

Revision received: $\quad 15.02 .2021$.

Accepted for publication: $\quad$ 05.04.2021.

Kako citirati ovaj rad? / How to cite this article?

Style - APA Sixth Edition:

Krivokapić, B. (2021, 04 15). Pravno uređenje položaja privatnih vojnih kompanija. (Z. Čekerevac, Ur.) FBIM Transactions, 9(1), 58-69. doi:10.12709/fbim.09.09.01.06

Style - Chicago Sixteenth Edition:

Krivokapić, Boris. 2021. „Pravno uređenje položaja privatnih vojnih kompanija.“ Urednik Zoran Čekerevac. FBIM Transactions (MESTE) 9 (1): 58-69. doi:10.12709/fbim.09.09.01.06.

Style - GOST Name Sort:

Krivokapić Boris Pravno uređenje položaja privatnih vojnih kompanija [Časopis] // FBIM Transactions / ur. Čekerevac Zoran. - Beograd : MESTE, 1504 2021. - 1 : T. 9. - str. 58-69.

Style - Harvard Anglia:

Krivokapić, B., 2021. Pravno uređenje položaja privatnih vojnih kompanija. FBIM Transactions, 15 04, 9(1), pp. 58-69.

Style - ISO 690 Numerical Reference:

Pravno uređenje položaja privatnih vojnih kompanija. Krivokapić, Boris. [ur.] Zoran Čekerevac. 1, Beograd : MESTE, 1504 2021, FBIM Transactions, T. 9, str. 58-69. 